\title{
Analysis of Brazilian wine competitiveness
}

\author{
D.A. Wurz ${ }^{1, a}$ and A.F. Brighenti ${ }^{2}$ \\ ${ }^{1}$ Santa Catarina Federal Institute, Av. Expedicionários, 2150, CEP 89460-000, Canoinhas, SC, Brazil \\ ${ }^{2}$ Santa Catarina State Agricultural Research and Rural Extension Agency (EPAGRI), João Araújo Lima Street, 102, CEP 88520-000, \\ São Joaquim, SC, Brazil
}

\begin{abstract}
The objective of this work was to evaluate Brazilian wine competitiveness in domestic market in relation to imported wines marketed in Brazil. The work is based on quantitative sources provided by different institutions: International Organization of Vine and Wine (OIV), Brazilian Union of Viticulture (UVIBRA), Ministry of Agriculture, Livestock, and Food Supply (MAPA) and Brazilian Agricultural Research Corporation (EMBRAPA). The data referring to marketing of Brazilian and imported wines refer to the period from 1993 to 2016; and for sparkling wines data refer to the period from 1998 to 2016. During the periods evaluated, there was a $73.86 \%$ increase in wine sales and a $446 \%$ increase in sparkling wines sale; however, when we compared the volume of Brazilian wines and Brazilian sparkling wines sold, there was a reduction of $38 \%$ in the marketing of these wines, while sparkling wines commercialization recorded an increase of $518 \%$ in the volume sold. Regarding the volume of imported products, there was an increase of $737 \%$ in imported wines marketing, and an increase of $275 \%$ in imported sparkling wines marketing. In 1993, only $19.3 \%$ of imported wines were sold in relation to the total volume marketed. As of 2016, imported wines accounted for $82.1 \%$ of the volume of wines sold in Brazil. For sparkling wines, there was an inverse situation, with a reduction in the marketing of imported sparkling wines in relation to the total sold, since in 1998 imported sparkling wine accounted for $29 \%$ of Brazilian sparkling wine market and in 2016 this percentage dropped to $18.2 \%$. It is concluded that sparkling wines are the products with greatest potential of Brazilian wine market. While still wines presents low competitiveness in relation to imported wines, being necessary to create market strategies that propitiate a greater acceptance of Brazilian wines, besides fiscal incentives to the grape producers and winemakers, reducing production costs, resulting in a lower price paid by final consumer.
\end{abstract}

\section{Introduction}

The viticulture presents great economic importance in Brazil, occupying an area of approximately 83,700 hectares, with an annual production varying between 1,300 and 1,400 thousand tons, in which about $40 \%$ of the production is destined for processing, where is posible to highlight the elaboration of still wines and sparkling wines [1]. According to Wurz et al. [2] in the last 20 years, there has been a transformation of Brazilian wine geography, with the emergence and consolidation of new regions, playing a fundamental role in increasing national wines quality.

Vitiviniculture has been an important activity for the economy of some regions, especially those located in southern Brazil, where the largest volume of grape, wine and other products is concentrated. The importance of the sector to these regions is entirely related to the sustainability of small and medium-sized rural companies, which produce table grapes and grapes for processing, as well as those that work in winemaking system, in order to contribute to the generation of employment and income for the economy of such regions [3].

However, when we evaluate wine consumption in Brazil, we observe in domestic market, an average

\footnotetext{
${ }^{a}$ Corresponding author: douglas . wurz@ifsc .edu.br
}

consumption of two liters per capita/year, much lower than that consumed in traditional wine producing countries, such as Argentina and Chile, for example. The reduced wine consumption can be explained by low purchasing power of Brazilian population in general, to cultural issues and the high prices of Brazilian wines [4].

Estimates indicate that in Brazilian population there are around 30 million regular wine consumers and 800 thousand wine enthusiasts. Brazilian consumers prefer red wine, followed by sparkling wines. White wines have a small, but growing, niche, while rosé wines have quite restricted consumption. The Brazilian has been educated in the last 15-20 years, drinking wines from Chile and Argentina. The Brazilian consumer has a great preference for imported wines [5].

The greater competitiveness in the international wine market, added with the opening of Brazilian economy to imported products in the 1990s, led to an increase in imports of wines to Brazilian market [6]. Having as main suppliers: Chile, Argentina, Portugal, Italy, France and Spain.

In this context, the objective of this work was to evaluate Brazilian wine competitiveness in domestic market in relation to imported wines marketed in Brazil. 


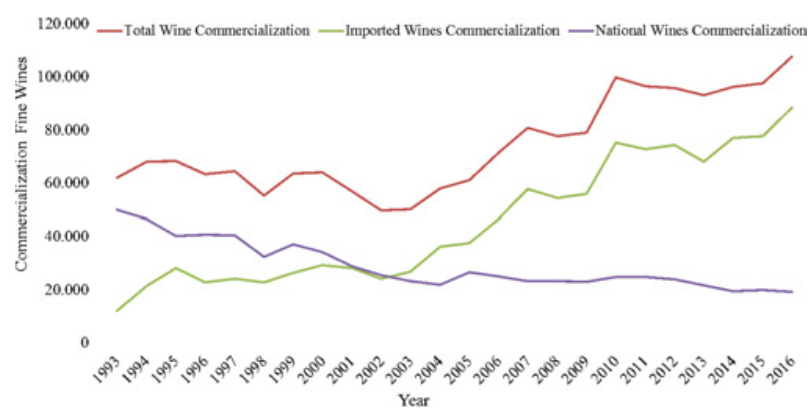

Figure 1. Evolution of the commercialization of wines in Brazil, in $1000 \mathrm{~L}$, between 1993 and 2016.

\section{Materials and methods}

The study was based on a review of scientific literature and oficial data published by institutions responsible for collecting and disseminating data on the production and marketing of fine wines and sparkling wines in Brazil. For a characterization of the Brazilian wine competitivenness, the following data were researched marketing of Brazilian and imported wines refer to the period from 1993 to 2016; and for sparkling wines data refer to the period from 1998 to 2016.

The institutions assessed were: Instituto Brasileiro do Vinho, IBRAVIN, Embrapa Uva e Vinho, Ministério da Agricultura, Pecuária e Abastecimento, MAPA and União Brasileira de Vitivinicultura, UVIBRA.

All collected data were used to generate graphs with the purpose of showing the panorama and determining trends of the commercialization of wines and sparkling wines in Brazil.

\section{Results and discussion}

Over the years there has been an increase in the volume of wines sold in Brazil (Fig. 1). However, at the same time that there is an increase in the commercialization of wines, there is a similar increase in the marketing of imported wines.

During the evaluated periods there was a $73.86 \%$ increase in wine sales and a $446 \%$ increase in the sale of sparkling wines; however, when we compared the volume of domestic wines and sparkling wines sold, there was a reduction of $38 \%$ in domestic wines sales (Fig. 1), while commercialization of sparkling wines increased by $518 \%$ (Fig. 2).

In relation to the volume of imported products, there was an increase of $737 \%$ in the marketing of imported wines (Fig. 1), and a $275 \%$ increase in the marketing of imported sparkling wines (Fig. 2).

In 1993 , only $19.3 \%$ of imported wines were sold in relation to the total volume marketed. But in 2016, imported wines accounted for $82.1 \%$ of the volume of wines sold in Brazil. According to Protas [7], for the segment of fine wines, with the process of Brazilian economy opening abroad in the early 1990s, Brazil faced a strong competition, registering significant growth rates of wine imports.

For sparkling wines, there was an inverse behavior, with a reduction in the marketing of imported sparkling wines in relation to the total sold, since in 1998 imported sparkling wine accounted for $29 \%$ of Brazilian sparkling

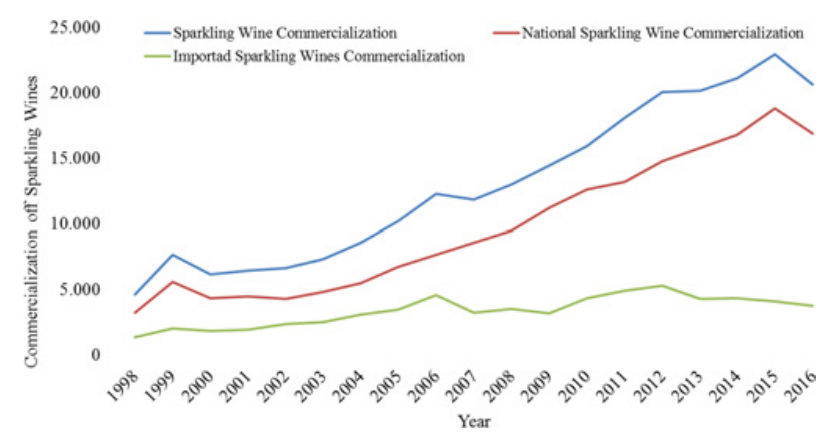

Figure 2. Commercialization volume (in $1000 \mathrm{~L}$ ) of sparkling wine in Brazil from 1989 to 2016.

wine market, and in 2016 this percentage dropped to $18.2 \%$ (Fig. 2). In a study made by Wurz et al. [8], it was observed that in Brazil the sparkling wines are the most promising wine-growing product, with the greatest potential to increase its commercialization, both in the domestic and abroad markets, especially Muscat sparkling wines.

The consumer market is dynamic, and is influenced by several factors. Thus, to be successful in this market, it is necessary to know for whom to sell, how much they buy, what their preferences, that is, who is the buyer and what he wants to buy [5]. Having information about the market trends, as well as the competitiveness of Brazilian wine, it is possible to define marketing strategies, seeking to attract a greater number of consumers, and concomitantly to this, an appreciation of national wines.

In view of the data presented, a consolidation of Brazilian domestic sparkling market has been observed over the last few years. These products are highly competitive in the market, while fine wines are subject to great competition with imported wines. That is, there is a low competitiveness of Brazilian wines in the Brazilian market.

\section{Conclusion}

It is concluded that sparkling wines are the products with greatest potential of Brazilian wine market. While still wines presents low competitiveness in relation to imported wines, being necessary to create market strategies that propitiate a greater acceptance of Brazilian wines, besides fiscal incentives to the grape producers and winemakers, reducing production costs, resulting in a lower price paid by final consumer.

\section{References}

[1] L.M.R. Mello, Vitivinicultura Brasileira: panorama 2013 (Comunicado Técnico 156, Embrapa Uva e Vinho, Bento Gonçalves, 6, 2014)

[2] D.A. Wurz, B.P, Bem, R. Allebrandt, B. Bonin, L.G. Dalmolin, A.T. Canossa, L. Rufato, A.A. Kretzschmar, Bio Web of Conferences, 9, 1 (2017)

[3] V.N. Duarte, Estudo da Cadeira Produtiva do Vinho em Santa Catarina: caractersticas e estgio atual. Evidências 13, 45-56 (2013)

[4] P.H. Hoeckel, C.A. Freitas, G.N.A. Oliveira. A concentração de mercado no setor vinícolas do 
Rio Grande do Sul (2004-2012), In: Encontro de Economia Gaúcha, 7, Anais...Porto Alegre: PUCRS. (2014)

[5] M. Copello, As regiões produtoras do Brasil Revista Anuário Vinho do Brasil, São Paulo, (2015)

[6] A.N. Almeida, C. Bragagnolo, A.L.S. Chagas, Revista de Economia e Sociologia Rural 53, 433-454 (2015)
[7] J.F. Protas, U.A. Camargo, L.M. Mello, A vitivinicultura brasileira: realidade e perspectivas (Embrapa Uva e Vinho, Bento Gonçalves, 2002)

[8] D.A. Wurz, R. Allebrandt, B.P. Bem, J. Reinher, A.T. Canossa, L.G. Dalmolin, L. Rufato, A.A. Kretzschmar, Brazilian sparkling wine: a successful trajectory. Bio Web of Conferences 9, 1-3 (2017) 